\title{
Hugo José SUAREZ (coord.), El sentido y el método. Sociologia de la cultura y analisis de contenido
}

Mexico, UNAM, El Colegio de Michoacan, 2008, 330 p.

\section{Michael Löwy}

\section{CpenEdition}

Journals

Édition électronique

URL : http://journals.openedition.org/assr/22088

DOI : $10.4000 /$ assr.22088

ISSN : $1777-5825$

Éditeur

Éditions de l'EHESS

Édition imprimée

Date de publication : 31 décembre 2010

Pagination : 9-242

ISBN : 9782713223013

ISSN : 0335-5985

\section{Référence électronique}

Michael Löwy, " Hugo José SUAREZ (coord.), El sentido y el método. Sociologia de la cultura y analisis de contenido ", Archives de sciences sociales des religions [En ligne], 152 | octobredécembre 2010, document 152-108, mis en ligne le 06 mai 2011, consulté le 21 septembre 2020. URL : http://journals.openedition.org/assr/22088 ; DOI : https://doi.org/10.4000/assr.22088 


\section{Hugo José SUAREZ (coord.), El sentido y el método. Sociologia de la cultura y analisis de contenido}

Mexico, UNAM, El Colegio de Michoacan, 2008, 330 p.

Michael Löwy

\section{RÉFÉRENCE}

Hugo José SUAREZ (coord.), El sentido y el método. Sociologia de la cultura y analisis de contenido, Mexico, UNAM, El Colegio de Michoacan, 2008, 330 p.

Ce volume, coordonné par un jeune chercheur latino-américain, rassemble des travaux théoriques et des recherches concrètes autour de la méthode d'analyse culturelle élaborée par les chercheurs belges Jean Rémy, Jean-Pierre Herniaux et Liliane Voyé. Il s'agit d'une forme d'analyse culturelle structurelle qui vise à rendre compte des conditions subjectives de l'action, notamment par l'analyse des contenus des discours, révélateurs de différents modèles culturels. Selon Fernando de Laire, dans un des essais de ce recueil, cette méthode est une sorte de «colonisation sociologique de la linguistique ».

Deux des travaux empiriques inspirés de cette méthode concernent les sciences sociales des religions. José Juan Osés étudie "la réincarnation comme théodicée " dans les croyances dans l' " au-délà » de quelques jeunes Belges wallons. Analysant les récits de vie dans plusieurs entretiens semi-ouverts, il montre - en utilisant quelques catégories de Max Weber - l'existence de deux formes parfaitement opposées de la croyance dans la réincarnation: une théodicée de la souffrance, qui répond à un besoin de compensation, et une théodicée du bonheur, qui correspond à un désir de légitimation. 
3 Hugo José Suarez, l'organisateur de ce volume, propose une passionnante étude de photos du mouvement cristero au Mexique. Comme l'on sait, la guerra cristera est un conflit ouvert qui opposa, de 1926 à 1929, l'Église à l'État mexicain, dont un des épisodes les plus frappants a été l'assassinat, en 1928, du général Obregon, président du Mexique, par le cristero José de Leon Toral - au cri de «Vive le Christ Roi ! ». Comme le montre très bien Suarez, les photos cristeras associent étroitement des images religieuses, familiales et guerrières, dans une théologie de la souffrance, du sacrifice et $\mathrm{du}$ martyre, typique du catholicisme traditionnel. Structurées de forme binaire, les photos opposent les martyrs et les bourreaux, les prêtres ou croyants exécutés et les soldats de l'Armée Fédérale. Le conflit s'est terminé par un compromis entre l'Église et l'État qui dure jusqu'à aujourd'hui. 